\title{
Sodium regulates Escherichia coli acid resistance, and influences GadX- and GadW-dependent activation of gadE
}

\author{
Hope Richard and John W. Foster
}

Correspondence

John W. Foster

fosterj@sungcg.usouthal.edu

Received 2 March 2007

Revised 16 May 2007

Accepted 28 May 2007

\author{
Department of Microbiology and Immunology, University of South Alabama, College of Medicine, \\ Mobile, AL 36688, USA
}

\begin{abstract}
Enteric bacteria must survive the extreme acid of the stomach ( $\mathrm{pH} 2$ or less) before entering the intestine where they can colonize and cause disease. Escherichia coli is superior to most other Enterobacteriaceae in surviving $\mathrm{pH} 2$ acid stress because it has four known acid-resistance systems, the most studied of which depends on glutamic acid. Glutamate-dependent acid resistance requires glutamate decarboxylase isozymes GadA and GadB, as well as a glutamate/ $\gamma$-aminobutyric acid antiporter encoded by gadC. The regulatory protein GadE is the essential activator of the gad $A$ and gadBC genes. The transcription of gadE, however, is controlled by numerous proteins. Two of these proteins, GadX and GadW, are AraC-family regulators whose sensory input signals are not known. Since $\mathrm{Na}^{+}$and $\mathrm{K}^{+}$play important roles in $\mathrm{pH}$ homeostasis, the contribution of these ions toward the regulation of this acid-resistance system was examined. The results indicated that a decrease in $\mathrm{Na}^{+}$, but not $\mathrm{K}^{+}$, concentration coincided with diminished acid resistance, and decreased expression of the $\operatorname{gad} E$, gad $A$ and gad $B C$ genes. However, $\mathrm{Na}^{+}$-dependent regulation of these genes dissipated in the absence of GadX and GadW. Since $\mathrm{Na}^{+}$levels did not regulate gadX or gadW transcription, it is proposed that GadX and GadW sense intracellular $\mathrm{Na}^{+}$concentration or some consequence of altered $\mathrm{Na}^{+}$levels.
\end{abstract}

\section{INTRODUCTION}

The extreme acid environment of the human stomach, which can reach pH 2 or less, is harsh for any enteric organism. Enteric pathogens must survive this level of $\mathrm{pH}$ for at least $2 \mathrm{~h}$, the average emptying time for the stomach, before reaching the intestine (Texter, 1968). To overcome this challenge, E. coli possesses four known acid-resistance systems (Foster \& Moreno, 1999; Gorden \& Small, 1993; Hersh et al., 1996; Iyer et al., 2003; Richard \& Foster, 2003). Acid-resistance (AR) system 1 (AR1), also referred to as the oxidative system, is a stationary-phase-induced glucoserepressed system that does not require the presence of an amino acid in the challenge medium to function (CastanieCornet et al., 1999). The other three systems (AR2, AR3 and AR4) are all amino-acid-dependent systems that require glutamate, arginine and lysine, respectively (Castanie-Cornet et al., 1999; Gong et al., 2003; Iyer et al., 2003; Lin et al., 1995).

All four AR systems provide different levels of protection. AR1 and AR4 provide a minimal level of protection, while AR3 provides moderate protection. The glutamatedependent (AR2) system is the most robust, and thus the most extensively studied. This system requires glutamate decarboxylase, encoded by $\operatorname{gad} A$ and $\operatorname{gadB}$, and a

Abbreviations: AR, acid-resistance; GABA, $\gamma$-aminobutyric acid; HTH, helix-turn-helix. glutamate $/ \gamma$-aminobutyric acid (GABA) antiporter (GadC) (Castanie-Cornet et al., 1999; De Biase et al., 1996, 1999; Hersh et al., 1996; Malashkevich et al., 1998; Richard \& Foster, 2003). GadA and GadB are isozymes of glutamate decarboxylase, and they are encoded by genes located at different sites on the chromosome (78.98 and $33.8 \mathrm{~min}$, respectively). The gadB and gadC genes are transcribed as an operon (De Biase et al., 1999). As internal $\mathrm{pH}$ becomes acidic, GadA/B converts intracellular glutamate to GABA, with the consumption of a proton and the release of $\mathrm{CO}_{2}$. The GABA produced in the decarboxylation reaction is then transported out of the cell through GadC, with the concomitant uptake of glutamate. A continuous cycle of proton consumption through amino-acid decarboxylation raises the internal $\mathrm{pH}$ of acid-stressed cells (Castanie-Cornet et al., 1999; Foster \& Moreno, 1999; Richard \& Foster, 2004). This increase in internal pH is thought to be required for survival in extreme acid stress.

Genetic regulation of this system is complex, and involves numerous regulators. Environmental signals such as acid and osmotic stress, as well as stationary phase signals, are important in inducing gadA/BC expression (CastanieCornet \& Foster, 2001; Castanie-Cornet et al., 1999; De Biase et al., 1999). Known transcriptional regulators include the alternative sigma factor RpoS, three AraC-family regulators (GadX, GadW and YdeO), cAMP and cAMP 
receptor protein, GadE (a LuxR-like regulator), TrmE (an Era-like GTPase), PhoP, EvgA/S (a two-component regulatory system) and the RcsCDB phosphorelay (CastanieCornet \& Foster, 2001; Castanie-Cornet et al., 2006, 1999; De Biase et al., 1999; Gong et al., 2004; Hommais et al., 2001; Ma et al., 2004, 2002, 2003b; Masuda \& Church, 2002, 2003; Tramonti et al., 2002; Zwir et al., 2005). The activity of each of these transcriptional regulators leads to the activation or repression of genes involved in glutamate-dependent acid resistance (Foster, 2004).

GadE is the essential activator of the $\operatorname{gad} A / B C$ genes. Most of the other regulators influence gadA $B C$ expression by controlling the expression of gadE. GadX and GadW are two AraC-like regulators that function in this regulatory circuit by controlling the expression of $\mathrm{gadE}$ and $\mathrm{gadA} / B C$ (Ma et al., 2003a; Tramonti et al., 2006; Sayed et al., 2007). These proteins are known to activate and repress $g a d A / B C$ and gadE under different growth conditions; however, the signal that influences their activity has yet to be identified (Ma et al., 2002; Tramonti et al., 2002).

Of interest to this study is the role of $\mathrm{Na}^{+}$and $\mathrm{K}^{+}$in regulating $\operatorname{gad} A / B C$ expression. We hypothesized that one or both of these ions might regulate acid resistance because they play such important roles in housekeeping $\mathrm{pH}$ homeostasis systems (Booth, 1985, 1999; Kroll \& Booth, 1983; Lewinson et al., 2004; Padan et al., 1981, 2005; Zilberstein et al., 1982). This investigation has revealed that $\mathrm{Na}^{+}$levels affect gadA/BC expression during growth into stationary phase. The effects of $\mathrm{Na}^{+}$on $\mathrm{gadA} / B C$ expression appear to be through the modulation of GadX and GadW activity, which, in turn, controls gadE expression.

\section{METHODS}

Strains, and culture conditions. The strains used in this study are listed in Table 1. Media included minimal $\mathrm{E}$ medium containing $0.4 \%$ glucose (EG) (Vogel \& Bonner, 1956), and $\mathrm{Na}^{+}-$and $\mathrm{K}^{+}$-deficient media (modified M63 medium; Miller, 1992) containing $15 \mathrm{mM}$ $\left(\mathrm{NH}_{4}\right) \mathrm{SO}_{4}, 18 \mu \mathrm{M} \mathrm{FeSO}_{4} .7 \mathrm{H}_{2} \mathrm{O}, 1 \mathrm{mM} \mathrm{MgSO}_{4}$ and $0.2 \%$ glucose. In addition, the $\mathrm{Na}^{+}$-deficient medium $(\mathrm{M} 63 \mathrm{~K})$ contained $100 \mathrm{mM}$ $\mathrm{KH}_{2} \mathrm{PO}_{4}$, while the $\mathrm{K}^{+}$-deficient medium $(\mathrm{M} 63 \mathrm{~N})$ contained $100 \mathrm{mM}$ $\mathrm{NaH}_{2} \mathrm{PO}_{4}$. A control medium (M63N/K) containing both $\mathrm{KH}_{2} \mathrm{PO}_{4}$ and $\mathrm{NaH}_{2} \mathrm{PO}_{4}$ in equal concentrations $(50 \mathrm{mM}$ of each) was also used. $\mathrm{M} 63 \mathrm{~N}^{0} / \mathrm{K}^{0}$, which was used for acid challenge only, contained $\left(\mathrm{NH}_{4}\right) \mathrm{SO}_{4}, \mathrm{FeSO}_{4} .7 \mathrm{H}_{2} \mathrm{O}, \mathrm{MgSO}_{4}$ and $0.2 \%$ glucose, with no added $\mathrm{NaH}_{2} \mathrm{PO}_{4}$ or $\mathrm{KH}_{2} \mathrm{PO}_{4}$. All $\mathrm{Na}^{+}$- and $\mathrm{K}^{+}$-deficient media were made with ultrapure chemicals and double-distilled water. $\mathrm{Na}^{+}$and $\mathrm{K}^{+}$measurements were made using $\mathrm{Na}^{+}$- and $\mathrm{K}^{+}$-specific combination electrodes (Orion ROSS $\mathrm{Na}^{+}$electrode; ThermoOrion ionplus $\mathrm{K}^{+}$electrode). For acid-resistance assays, the acid challenge medium or $\mathrm{H}_{2} \mathrm{O}$ was prepared at $\mathrm{pH} 2.5$ (adjusted with $\mathrm{HCl}$ ). Cultures were grown at $37^{\circ} \mathrm{C}$, with shaking at 220 r.p.m., overnight $(18 \mathrm{~h})$ to stationary phase.

Acid-resistance assays. Acid-resistance assays were performed as described previously (Castanie-Cornet et al., 1999). Briefly, cells were grown overnight in EG, M63K, M63N or $\mathrm{M} 63 \mathrm{~N} / \mathrm{K}$ at $\mathrm{pH} 5.5$. Stationary-phase cultures were diluted 1:1000 into prewarmed $\mathrm{pH} 2.5 \mathrm{M} 63 \mathrm{~K}, \mathrm{M} 63 \mathrm{~N}, \mathrm{M} 63 \mathrm{~N} / \mathrm{K}$ or $\mathrm{H}_{2} \mathrm{O}$, with or without $1.6 \mathrm{mM}$ glutamate. To determine if $\mathrm{Na}^{+}$or $\mathrm{K}^{+}$was required during acid challenge, cells were grown in minimal EG medium at $\mathrm{pH} 5.5$ to stationary phase. Cells were then harvested, and washed three times in an equal volume of $\mathrm{MC}$ buffer $\left(10 \mathrm{mM} \mathrm{MgCl}_{2}\right.$ and $5 \mathrm{mM}$ $\mathrm{CaCl}_{2}$ ) to remove excess $\mathrm{Na}^{+}$and $\mathrm{K}^{+}$from the cells. After the final wash, cells were resuspended in an equal volume of MC buffer, and subsequently diluted 1:1000 into the $\mathrm{pH} 2.5$ challenge media indicated (Fig. 1). At various time points, $10 \mu \mathrm{l}$ aliquots were removed and serially diluted, and $10 \mu \mathrm{l}$ of each dilution was plated on Luria-Bertani (LB) agar. The numbers of c.f.u. were determined, and percentage survival was calculated relative to time zero.

Western blot analysis. Cells were cultured overnight in $3 \mathrm{ml}$ of the indicated media (Fig. 2) at $\mathrm{pH}$ 5.5. Cells were then harvested by centrifugation at $4500 \mathrm{~g}$ for $5 \mathrm{~min}\left(4^{\circ} \mathrm{C}\right)$, and resuspended in $50 \mu \mathrm{l}$ $0.1 \%$ SDS. Protein concentrations were measured using the Bio-Rad protein assay reagent. Protein $(5 \mu \mathrm{g})$ was separated on $10 \%$ polyacrylamide-SDS gels (Bio-Rad), and then transferred to Immobilon-P (PVDF) membranes with a Semiphore transfer cell (Hoefer Scientific) at $100 \mathrm{~mA}$ for $2 \mathrm{~h}$. Membranes were blocked with $5 \%$ nonfat milk in Trisbuffered saline (10 mM Tris, $\mathrm{pH} 8,150 \mathrm{mM} \mathrm{NaCl}$ ) containing Tween 20 , and incubated with rat $(\mathrm{GadA} / \mathrm{B})$ or rabbit $(\mathrm{GadC})$ primary antibodies for $1 \mathrm{~h}$, followed by incubation with anti-rat or -rabbit

Table 1. Strains used in this study

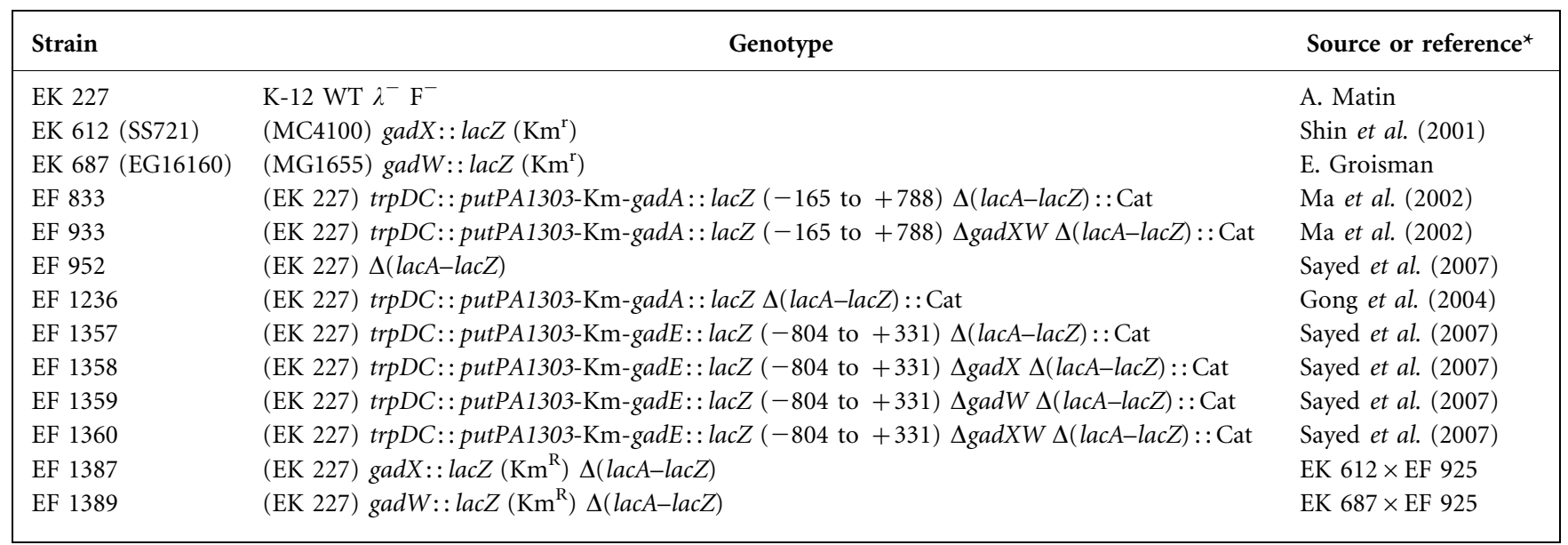

${ }^{\star}$ A. Matin, Stanford University, Palo Alto, CA, USA; E. Groisman, Washington University, St Louis, MO, USA. 


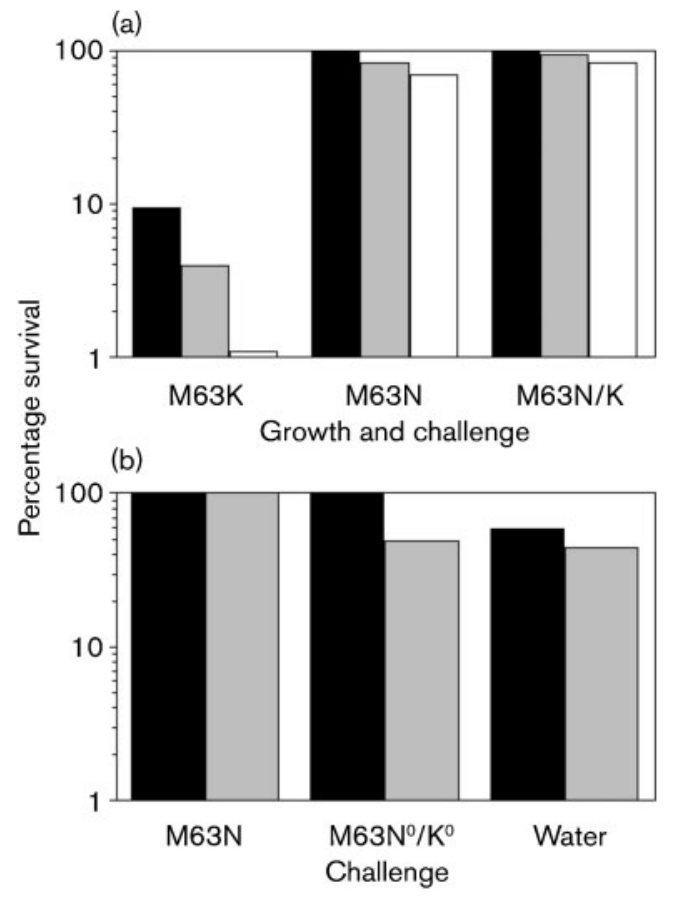

Fig. 1. $\mathrm{Na}^{+}$and $\mathrm{K}^{+}$effects on $\mathrm{AR} 2$ function. (a) Cells were grown $(\mathrm{pH} 5.5)$ and challenged $(\mathrm{pH} \mathrm{2.5)}$ in the media indicated. Acid challenge was conducted in the presence and absence of glutamic acid $\mathrm{HCl}$. Dilutions of 1:1000 were made from an overnight culture into the challenge media. Cells were not washed for this experiment because they were grown and challenged in the same medium, and therefore there would be no ion carry over. Aliquots $(10 \mu \mathrm{l})$ were removed at 1 (black bars), 2 (grey bars) and $4 \mathrm{~h}$ (white bars), serially diluted, and plated on LB. The numbers of c.f.u. were determined, and percentage survival was calculated relative to time 0 . (b) Cells were grown in EG pH 5.5, washed three times in $\mathrm{MC}$ buffer, and then diluted 1:1000 into the media indicated, in the absence and presence of glutamic acid. Aliquots were removed at 2 (black bars) and $3 \mathrm{~h}$ (grey bars), serially diluted, and plated on LB to determine c.f.u. $(a, b)$ Survival results in the presence of glutamic acid are shown; survival of all cultures challenged in the absence of glutamate was below the level of detection. The bars represent mean values of triplicate assays. Replicate values did not vary by more that $10 \%$ from the mean.

secondary antibodies for $1 \mathrm{~h}$ at room temperature. The blot was developed with ECL detection reagents (Amersham Pharmacia Biotech).

$\boldsymbol{\beta}$-Galactosidase assays. $\beta$-Galactosidase assays were performed according to Miller (1992). Cells were cultured in the indicated medium to stationary phase, and $100 \mu \mathrm{l}$ of the stationary phase culture was used in the assay.

\section{RESULTS}

\section{$\mathrm{Na}^{+}$contributes to AR2-mediated survival}

$\mathrm{Na}^{+}$and $\mathrm{K}^{+}$have central roles in $\mathrm{pH}$ homeostasis during growth at different $\mathrm{pH}$ values. It is thought that $\mathrm{Na}^{+} / \mathrm{H}^{+}$

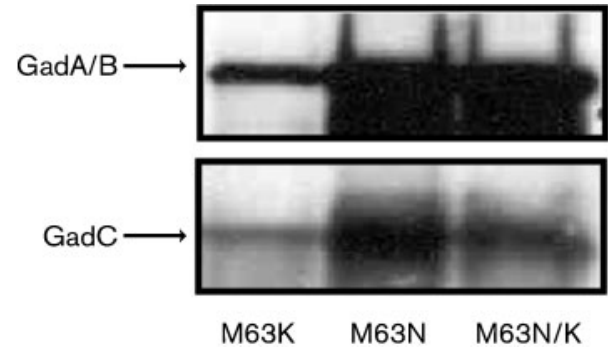

Fig. 2. Western blot analysis of $G a d A / B$ and $G a d C$ under different growth conditions. Cells grown to stationary phase in the media indicated, at $\mathrm{pH} 5.5$, were harvested, resuspended in $0.1 \%$ SDS, and the proteins were separated on a $10 \% \mathrm{Tris} / \mathrm{HCl}$ polyacrylamide gel. Membranes were then probed with either antiGadA/B- or anti-GadC-specific antibodies.

and $\mathrm{K}^{+} / \mathrm{H}^{+}$antiporter systems help maintain cytoplasmic $\mathrm{pH}$ near 7.8 when cells are growing under alkaline and acidic conditions, respectively (Booth, 1985). Consequently, potential roles for these ions in surviving extreme acid stress were investigated. Cells were grown to stationary phase in $\mathrm{M} 63 \mathrm{~K}, \mathrm{M} 63 \mathrm{~N}$ or $\mathrm{M} 63 \mathrm{~N} / \mathrm{K}$ at $\mathrm{pH} 5.5$, and subsequently challenged in the same medium at $\mathrm{pH} 2.5$. When cells were grown and acid challenged in M63N (a high- $\mathrm{Na}^{+}$, low- $\mathrm{K}^{+}$condition), survival was $84 \%$ after $2 \mathrm{~h}$ (Fig. 1a). A similar result was observed when cells were both grown and acid challenged in M63N/K (containing an intermediate level of both $\mathrm{Na}^{+}$and $\mathrm{K}^{+}$) (Fig. 1a). However, when cells were grown and challenged in M63K (a low- $\mathrm{Na}^{+}$, high- $\mathrm{K}^{+}$condition), survival was only $3 \%$ after $2 \mathrm{~h}$ at $\mathrm{pH} 2.5$ (Fig. 1a). The data suggest that $\mathrm{Na}^{+}$is important to acid resistance. However, it was unclear whether $\mathrm{Na}^{+}$was more important during cell growth (i.e. during the induction of acid resistance), or during acid challenge (i.e. via the actual mechanism of acid resistance).

As noted above, $\mathrm{Na}^{+}$can function as a counter-ion in antiport mechanisms that directly remove $\mathrm{H}^{+}$from the cytoplasm (Karpel et al., 1991; Kroll \& Booth, 1983; Zilberstein et al., 1982). Alternatively, $\mathrm{Na}^{+}$could act at the gene level by influencing the induction of key system components (Rahav-Manor et al., 1992). We first determined whether $\mathrm{Na}^{+}$or $\mathrm{K}^{+}$played a physiological role in the mechanism of acid survival. The $g a d A / B C$ genes were induced by growth to stationary phase in $\mathrm{pH} 5.5$ minimal EG medium, which is a high- $\mathrm{Na}^{+}$, high- $\mathrm{K}^{+}$medium. The induced cells were then extensively washed to remove excess $\mathrm{Na}^{+}$and $\mathrm{K}^{+}$, and subsequently challenged in $\mathrm{M} 63 \mathrm{~N}, \mathrm{M} 63 \mathrm{~N}^{0} / \mathrm{K}^{0}$ (containing no added $\mathrm{Na}^{+}$or $\mathrm{K}^{+}$) or $\mathrm{H}_{2} \mathrm{O}$, at $\mathrm{pH} 2.5$, in the presence or absence of glutamic acid (Fig. 1b). Remarkably, cells survived equally well under all challenge conditions when glutamic acid was present. This result indicates that neither $\mathrm{Na}^{+}$nor $\mathrm{K}^{+}$plays a major physiological role during $\mathrm{pH} 2.5$ acid stress. 


\section{$\mathrm{Na}^{+}$levels affect gadA/BC expression}

Glutamate decarboxylase and the GadC antiporter are critical components of AR2. To determine whether $\mathrm{Na}^{+}$or $\mathrm{K}^{+}$regulates gadA/BC expression, Western blot analyses were performed to examine the levels of GadA/BC proteins. Cells grown to stationary phase in M63K, M63N and $\mathrm{M} 63 \mathrm{~N} / \mathrm{K}$ were harvested, and solubilized in $0.1 \%$ SDS. Cells cultured in media containing high levels of $\mathrm{Na}^{+}$ (either M63N or M63N/K) expressed GadA/BC proteins at high levels (Fig. 2, lanes 2 and 3). In contrast, Fig. 2 (lane 1) shows that cells grown in M63K (low $\mathrm{Na}^{+}$, high $\mathrm{K}^{+}$) poorly expressed the GadA/B decarboxylases and GadC antiporter. This corresponds to the lower level of acid resistance seen under these conditions in Fig. 1(a). These findings suggest that high $\mathrm{Na}^{+}$levels are involved in inducing gadA/BC expression.

The expressions of $\operatorname{gadA}$ and $\operatorname{gadBC}$ are controlled at the transcriptional, as well as the translational, level (CastanieCornet \& Foster, 2001; De Biase et al., 1999; Gong et al., 2004). We next examined which of these levels was influenced by high $\mathrm{Na}^{+}$by using gadA : lacZ transcriptional and translational fusions. The results shown in Fig. 3(a, b) indicate that cells grown under high- $\mathrm{Na}^{+}$(low$\mathrm{K}^{+}$) conditions $(\mathrm{M} 63 \mathrm{~N})$ exhibit a 5.8-fold higher $\beta$ galactosidase activity compared with cells cultured in a

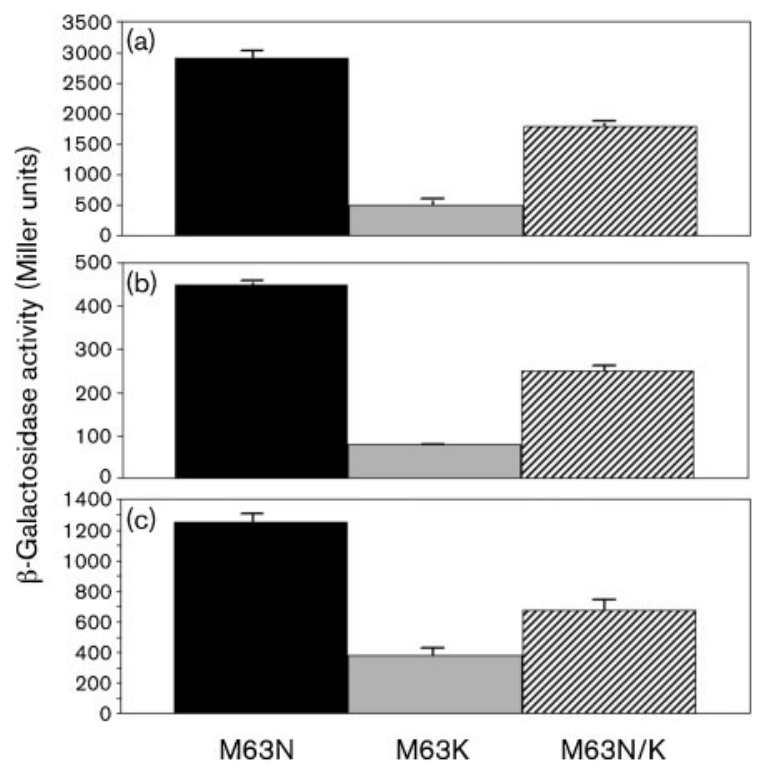

Fig. 3. gad $A$ and gadE : : lacZ expression is $\mathrm{Na}^{+} / \mathrm{K}^{+}$dependent. $(\mathrm{a}-\mathrm{c})$ Strains containing a gad $A$ : : lac $Z$ transcriptional fusion (EF 833; $\operatorname{gad} A:: \operatorname{lac} Z_{(\mathrm{O})}$ ) (a), a translational fusion (EF 1236; $\left.\operatorname{gad} A: \operatorname{lac} Z_{(\mathrm{P})}\right)(\mathrm{b})$, and a $\operatorname{gad} E:$ : lac $Z_{(\mathrm{O})}$ transcriptional fusion (EF 1357) (c), were grown in the media indicated at $\mathrm{pH} 5.5$ to stationary phase (media supplemented with $0.3 \mathrm{mM}$ tryptophan). These cultures were then assayed for $\beta$-galactosidase activity. The data shown are representative of at least three separate experiments; bars represent SEM. high- $\mathrm{K}^{+}\left(\right.$low- $\left.\mathrm{Na}^{+}\right)$condition $(\mathrm{M} 63 \mathrm{~K})$. Cells grown at intermediate $\mathrm{Na}^{+} / \mathrm{K}^{+}$concentrations $(\mathrm{M} 63 \mathrm{~N} / \mathrm{K})$ induced $\operatorname{gadA}$ at a level that was 3.4-fold above the expression seen with cells grown in low- $\mathrm{Na}^{+}$M63K medium (Fig. 3a, b). Because similar fold differences were obtained when a gadA : lac $Z$ translational fusion was examined, it appears that $\mathrm{Na}^{+}$levels affected $g a d A / B C$ transcription, not translation, during growth to stationary phase (Fig. $3 b$ ).

One might argue that the ion-dependent expression of this system is due to low $\mathrm{K}^{+}$rather than high $\mathrm{Na}^{+}$levels. That is, high $\mathrm{K}^{+}$levels repress the system, rather than high $\mathrm{Na}^{+}$ levels induce it. However, the effects are probably not due to low $\mathrm{K}^{+}$, based on results we will show later using $\operatorname{gadX}$ and gadW mutants.

\section{The expression of GadE, the essential activator of $\operatorname{gad} A / B C$, is also regulated by $\mathrm{Na}^{+}$levels}

Of the known activators of gadA and $g a d B C$, GadE appears to be the most important. Thus, we wondered whether the effect of $\mathrm{Na}^{+}$levels on gadA/BC expression might really be due to an influence of these ions on gadE expression. This question was addressed by examining the influence of $\mathrm{Na}^{+}$ and $\mathrm{K}^{+}$on the expression of a gadE: : lacZ transcriptional fusion strain. When cells containing a gadE: : lac $Z$ fusion were cultured in $\mathrm{M} 63 \mathrm{~N}$ (high $\mathrm{Na}^{+}$), gadE expression was threefold higher than that produced when the cells were grown in $\mathrm{M} 63 \mathrm{~K}$ (low $\mathrm{Na}^{+}$), and 1.75-fold higher than levels made during growth in M63N/K (Fig. 3c). The results indicate that gadE transcription is regulated by $\mathrm{Na}^{+}$ levels. Since GadE is a required activator of gadA and $\operatorname{gadBC}$, the $\mathrm{Na}^{+}$dependence of $\mathrm{gadA} / B C$ is likely to be due to $\mathrm{Na}^{+}$-dependent regulation of $\mathrm{gadE}$.

\section{GadX and GadW affect the $\mathrm{Na}^{+}$-dependent regulation of gadE and gadA}

GadX and GadW are two AraC-family regulators that activate the expression of $\operatorname{gadA}, \mathrm{gadB} / \mathrm{C}$ and $\operatorname{gadE}(\mathrm{Ma}$ et al., 2002; Tramonti et al., 2002; Sayed et al., 2007). Therefore, we questioned whether GadX and/or GadW play a role in the $\mathrm{Na}^{+}$-dependent regulation of $g a d E$, as well as that of $g a d A$. Wild-type (WT) and $\Delta g a d X / W$ strains carrying the gadA: : lacZ reporter were cultured in M63K, $\mathrm{M} 63 \mathrm{~N}$ and $\mathrm{M} 63 \mathrm{~N} / \mathrm{K}$. The results presented in Fig. 4(a) indicate that the $\mathrm{Na}^{+}$-dependent induction of gadA exhibited by the WT is lost in the $\triangle X W$ mutant. A similar pattern was observed when we examined the gadE: lacZ reporter strain (Fig. 4b). The $\Delta g a d X / W$ strain again failed to induce $\mathrm{gadE}$ in the high- $\mathrm{Na}^{+} /$low- $\mathrm{K}^{+}$medium (Fig. 4b).

A report by others has shown that GadE alone can activate gadA/BC expression in vivo, but that GadE is required for GadX or GadW to activate these genes (Sayed et al., 2007). Thus, these data suggest that GadX and GadW affect $\mathrm{Na}^{+}$dependent gadA expression indirectly through the $\mathrm{Na}^{+}$dependent regulation of gadE. 


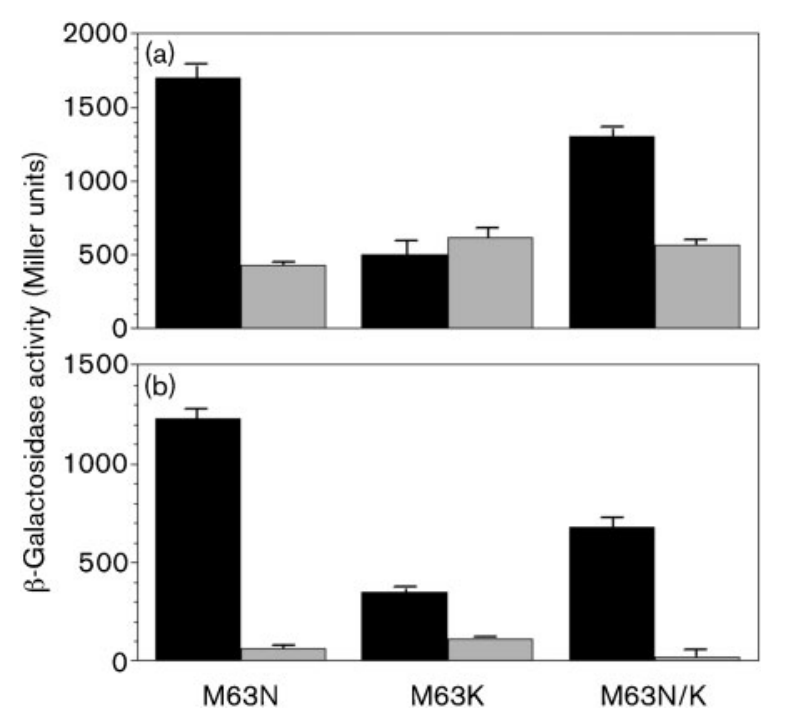

Fig. 4. $\mathrm{GadX}$ and $\mathrm{GadW}$ affect the $\mathrm{Na}^{+} / \mathrm{K}^{+}$-dependent regulation of $\operatorname{gad} A$ and $\operatorname{gad} E .(\mathrm{a}, \mathrm{b}) \mathrm{A}$ gadXW deletion was introduced into strains containing $\operatorname{gad} A$ ::lacZ (a), and $\operatorname{gadE}:$ : lacZ (b) fusions. The derivative strains were then grown to stationary phase in the media indicated supplemented with tryptophan, at $\mathrm{pH} 5.5$, and assayed for $\beta$-galactosidase activity, along with WT strains carrying the same fusions. Black bars, WT; grey bars, gadXW deletion mutant. Values are means of triplicate assays and the bars represent SEM.

\section{GadX and GadW differentially affect gadE : : lacZ expression}

The individual effects of GadX and GadW were then analysed to determine whether distinct roles exist for each of these two proteins in gadE expression. In WT cells possessing both $\mathrm{gadX}^{+}$and $\mathrm{gad} W^{+}$, gadE was induced in high $\mathrm{Na}^{+}$/low K ${ }^{+}$(Fig. 5, bar 1 versus bar 5). Either GadX or GadW alone could carry out this activation (Fig. 5, bars 2 and 3 versus bar 4).

The situation was different in low- $\mathrm{Na}^{+}$conditions. Here, deleting GadX, while retaining GadW $\left(\Delta \operatorname{gadX} \operatorname{gad} W^{+}\right)$, actually increased low $\mathrm{Na}^{+}$expression of gadE compared with WT cells (Fig. 5, bar 5 versus bar 6). This suggests that GadW can activate gadE in low $\mathrm{Na}^{+}$, and that GadX normally prevents or inhibits this. In contrast, when GadX was retained, and GadW was removed $\left(\operatorname{gad} X^{+} \Delta \operatorname{gadW}\right)$, there was little effect on low $\mathrm{Na}^{+}$expression of gadE (Fig. 5, bars 5 and 7). However, GadX was still needed to activate gadE in low $\mathrm{Na}^{+}$, as seen when comparing the gadW and $\operatorname{gadXW}$ results (Fig. 5, compare bars 7 and 8). These data can be explained as GadX repressing the activity of GadW, while also directly activating gadE, under low- $\mathrm{Na}^{+}$ conditions. Under high- $\mathrm{Na}^{+}$conditions, however, GadX and $\mathrm{W}$ had an additive effect on the expression of $g a d E$ (Fig. 5, bars 1 versus bars 2 and 3). As for the effect of these mutations on acid resistance, mutants individually defective in $g a d X$ or gadW remained acid resistant following

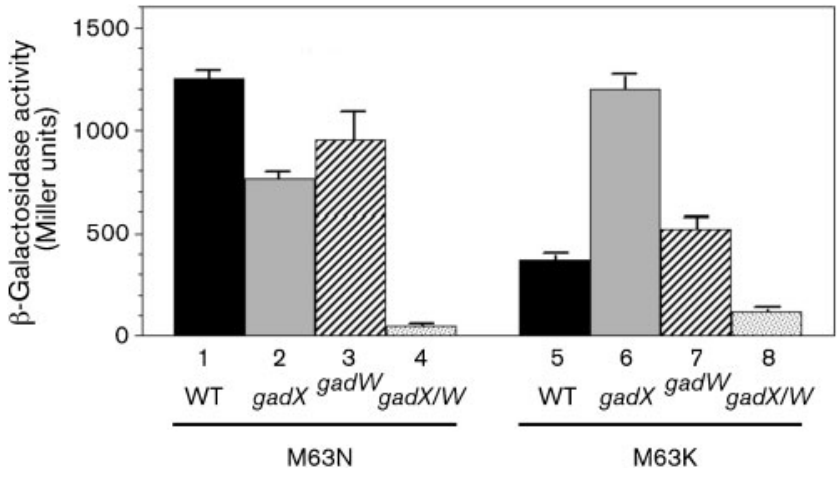

Fig. 5. GadX and GadW exhibit a differential effect on the $\mathrm{Na}^{+} /$ $\mathrm{K}^{+}$regulation of gadE expression. Strains carrying a gadE : : lacZ transcriptional fusion were introduced with a gad $X$, gadW or gadXW (same strain as Fig. 4) mutation. These strains were then grown to stationary phase in the media indicated, at $\mathrm{pH} 5.5$, and assayed for $\beta$-galactosidase activity, along with the WT. Values are means of triplicate assays and the bars represent SEM.

growth in high $\mathrm{Na}^{+}$because of the redundant effects of GadX and GadW on gadE induction (50-60\% survival after $4 \mathrm{~h}$ at $\mathrm{pH} 2.5$ ). In low $\mathrm{Na}^{+}$, however, gadX mutants were actually more acid resistant than the $\mathrm{WT}$, exhibiting $10 \%$ survival versus $1 \%$ survival, respectively, after $4 \mathrm{~h}$ at $\mathrm{pH}$ 2.5. This occurs because, as shown in Fig. 5, GadW is better at activating gadE when GadX is absent.

As noted above, one might argue that the ion-dependent expression of this system is due to low $\mathrm{K}^{+}$rather than high $\mathrm{Na}^{+}$levels. That is, high $\mathrm{K}^{+}$levels repress the system rather than high $\mathrm{Na}^{+}$levels induce it. However, the effects are probably not due to $\mathrm{K}^{+}$. When both $\mathrm{K}^{+}$and $\mathrm{Na}^{+}$were high (as in NK medium), the gadX and gadW phenotypes were similar to those seen using the high- $\mathrm{Na}^{+} /$low- $\mathrm{K}^{+}$ medium, i.e. both GadX and GadW were needed for maximal expression of gadA and gadE (data not shown). If high $\mathrm{K}^{+}$was the sensed condition, one would have expected that the gadX/gadW phenotypes observed in $\mathrm{M} 63 \mathrm{~N} / \mathrm{K}$ medium would be similar to those seen in M63K medium. They were not.

\section{$\mathrm{Na}^{+} / \mathrm{K}^{+}$levels do not regulate expression of $\mathrm{gadX}$ and gadW}

We next examined whether the $\mathrm{Na}^{+}$effect on gadE and gadA expression was due to $\mathrm{Na}^{+} / \mathrm{K}^{+}$effects on $\operatorname{gadX}$ or gadW expression. Strains containing gadX::lac $Z$ or gad $W$ : : lacZ fusions were grown in high- $\mathrm{Na}^{+}(\mathrm{M} 63 \mathrm{~N})$, low- $\mathrm{Na}^{+} \quad(\mathrm{M} 63 \mathrm{~K})$ and intermediate- $\mathrm{Na}^{+} \quad(\mathrm{M} 63 \mathrm{~N} / \mathrm{K})$ media, and the effects on expression were determined. The results shown in Fig. 6 reveal that $\mathrm{Na}^{+}$levels had no significant effect on the transcription of either $g a d X:$ lac $Z$ or gadW: : lac $Z$, suggesting that $\mathrm{Na}^{+}$-dependent regulation of $g a d A$ and $g a d E$ is due to the post-transcriptional 


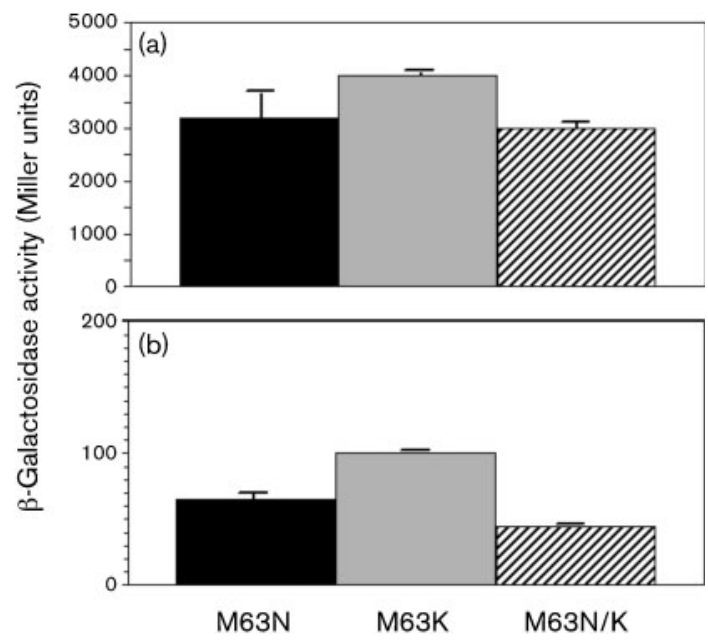

Fig. 6. gadX and gadW expression is not $\mathrm{Na}^{+} / \mathrm{K}^{+}$dependent. Strains carrying a gad $X$ : : lac $Z$ fusion (a), and a gadW : : lac $Z$ fusion (b), were grown to stationary phase in the media indicated, at $\mathrm{pH} 5.5$, and then assayed for $\beta$-galactosidase activity.

modulation of GadX and GadW activity, and not to their levels of expression.

\section{DISCUSSION}

E. coli is an acid-resistant enteric micro-organism capable of withstanding extreme acid exposure for several hours (Small et al., 1994; Small, 1998). AR2, the glutamatedependent system, is the most robust of the four systems that protect E. coli from acid stresses encountered in the environment and in the stomach of the host (CastanieCornet et al., 1999; Iyer et al., 2003; Price et al., 2004). A complex web of regulation controls AR2 expression, and this allows cells to anticipate future exposures to acid stress when growing under a variety of conditions (CastanieCornet \& Foster, 2001; Castanie-Cornet et al., 1999; De Biase et al., 1999; Gong et al., 2004; Hommais et al., 2001; Ma et al., 2003a, 2004, 2002; Masuda \& Church, 2002, 2003; Tramonti et al., 2002). Production of GadE is the focus of much of this regulatory network. Numerous regulatory proteins are known to control gadE expression, including GadE itself, GadX, GadW, CRP, RpoS, YdeO, EvgAS, PhoP and RcsCDB. Despite knowledge of these many regulators, little is known regarding what small molecules influence their activities.

Previous work has shown that cAMP levels affect induction of acid resistance by controlling RpoS production, which, in turn, activates expression of a small RNA ( GadY) needed to stabilize gadX mRNA (Jung \& Kim, 2003; Ma et al., 2003a; Opdyke et al., 2004). In addition to cAMP, microarray studies have implicated PhoP, which senses $\mathrm{Mg}^{+}$, as a regulator of $\mathrm{gadE}$ (Zwir et al., 2005). The current work indicates that $\mathrm{Na}^{+}$is also involved in this extensive regulatory network. However, it is not clear whether the system senses internal or external $\mathrm{Na}^{+}$levels, since altering external $\mathrm{Na}^{+}$concentration will also influence internal $\mathrm{Na}^{+}$concentration. For instance, it has been shown that changing external $\mathrm{Na}^{+}$levels from $1 \mathrm{mM}$ to $85 \mathrm{mM}$ will change internal $\mathrm{Na}^{+}$levels from $5 \mathrm{mM}$ to $14 \mathrm{mM}$ (Lo et al., 2006).

Since GadE is the central activator of $\operatorname{gad} A$ and $\operatorname{gadBC}$, it would seem reasonable that the effect of $\mathrm{Na}^{+}$on $\operatorname{gad} A / B C$ expression would be indirect via an effect on GadE activity or expression. GadE belongs to the LuxR family of transcriptional regulators, with homology in the helixturn-helix (HTH) DNA-binding domain (Fuqua et al., 1994). The LuxR family of regulators is separated into two classes, both of which depend on a chemical or environmental signal to activate or inactivate them (Nasser \& Reverchon, 2007; Withers et al., 2001). However, $\mathrm{Na}^{+}$does not appear to be a signal sensed directly by GadE; instead, $\mathrm{Na}^{+}$appears to affect the expression of gadE via influences over GadX and GadW.

GadX and GadW are two AraC-like regulators that have been shown to regulate $\operatorname{gad} A / B C$ expression (Ma et al., 2002; Tramonti et al., 2002), and have more recently been established as regulators of gadE expression (Sayed et al., 2007). Members of the AraC/XylS family of regulators possess a DNA-binding domain (HTH motif), as well as a dimerization domain (Gallegos et al., 1997). Many of these proteins are also capable of binding ligands, such as arabinose in the case of AraC, that modulate their activity (Gallegos et al., 1997). The data presented indicate that the $\mathrm{Na}^{+}$level during growth can modulate the activities of GadX and GadW. However, it is not certain whether GadX and/or GadW actually bind $\mathrm{Na}^{+}$, or if external $\mathrm{Na}^{+}$ somehow alters their activities.

The working model fitting the current data suggests that GadW can activate gadE regardless of $\mathrm{Na}^{+}$levels. GadX, on the other hand, will activate transcription of gadE when $\mathrm{Na}^{+}$levels are high. However, when $\mathrm{Na}^{+}$levels are low, GadX appears to inhibit GadW activity. Because $\mathrm{Na}^{+}$levels did not affect the expression of $\operatorname{gadX}$ and gadW operon fusions (Fig. 6), it seems that $\mathrm{Na}^{+}$post-transcriptionally modulates the activity of these two regulators.

The mechanism by which $\mathrm{Na}^{+}$modulates GadX and GadW activities is not known. There is some evidence that GadX and GadW can form both homodimers and heterodimers (Ma et al., 2002). Therefore, assuming that the $\mathrm{Na}^{+}$effect is post-translational and intracellular, the level of $\mathrm{Na}^{+}$inside the cell may change the effectiveness of these interactions, thereby changing the activity of the proteins. It is also possible that this ion does not affect protein-protein interaction, but affects the activity of the protein directly via ion binding. Alternatively, $\mathrm{Na}^{+}$may cause some other unknown physiological effect inside the cell that then modulates the activity of GadX and GadW.

It is known that changing external $\mathrm{Na}^{+}$levels from $1 \mathrm{mM}$ to $85 \mathrm{mM}$ changes internal $\mathrm{Na}^{+}$levels from $5 \mathrm{mM}$ to 
$14 \mathrm{mM}$ (Lo et al., 2006). Other published measurements indicate that growth $\mathrm{pH}$ also alters intracellular $\mathrm{Na}^{+}$levels, changing them from approximately $0.1 \mu \mathrm{mol}$ (mg protein $)^{-1}$ to $0.4 \mu \mathrm{mol}(\mathrm{mg} \text { protein })^{-1}$ during growth at pH 8.3 and 6, respectively (Shijuku et al., 2001). Thus, even though we cannot rule out the possibility that external $\mathrm{Na}^{+}$levels are responsible for the effects seen, the evidence that external $\mathrm{Na}^{+}$levels and $\mathrm{pH}$ affect internal $\mathrm{Na}^{+}$levels is consistent with the idea that an acid-associated increase in internal $\mathrm{Na}^{+}$levels could contribute to the acid induction of the GAD system.

\section{ACKNOWLEDGEMENTS}

The authors would like to thank Jon Audia, Herbert Winkler, David Wood and Michael Spector for stimulating discussions.

\section{REFERENCES}

Booth, I. R. (1985). Regulation of cytoplasmic $\mathrm{pH}$ in bacteria. Microbiol Rev 49, 359-378.

Booth, I. R. (1999). The regulation of intracellular $\mathrm{pH}$ in bacteria. In Bacterial Response to pH, pp. 19-27. Chichester: Wiley.

Castanie-Cornet, M. P. \& Foster, J. W. (2001). Escherichia coli acid resistance: cAMP receptor protein and a $20 \mathrm{bp}$ cis-acting sequence control $\mathrm{pH}$ and stationary phase expression of the gadA and gadBC glutamate decarboxylase genes. Microbiology 147, 709-715.

Castanie-Cornet, M. P., Penfound, T. A., Smith, D., Elliott, J. F. \& Foster, J. W. (1999). Control of acid resistance in Escherichia coli. J Bacteriol 181, 3525-3535.

Castanie-Cornet, M. P., Cam, K. \& Jacq, A. (2006). RcsF is an outer membrane lipoprotein involved in the RcsCDB phosphorelay signaling pathway in Escherichia coli. J Bacteriol 188, 4264-4270.

De Biase, D., Tramonti, A., John, R. A. \& Bossa, F. (1996). Isolation, overexpression, and biochemical characterization of the two isoforms of glutamic acid decarboxylase from Escherichia coli. Protein Expr Purif 8, 430-438.

De Biase, D., Tramonti, A., Bossa, F. \& Visca, P. (1999). The response to stationary-phase stress conditions in Escherichia coli: role and regulation of the glutamic acid decarboxylase system. Mol Microbiol 32, 1198-1211.

Foster, J. W. (2004). Escherichia coli acid resistance: tales of an amateur acidophile. Nat Rev Microbiol 2, 898-907.

Foster, J. W. \& Moreno, M. (1999). Inducible acid tolerance mechanisms in enteric bacteria. Novartis Found Symp 221, 55-69.

Fuqua, W. C., Winans, S. C. \& Greenberg, E. P. (1994). Quorum sensing in bacteria: the LuxR-LuxI family of cell density-responsive transcriptional regulators. J Bacteriol 176, 269-275.

Gallegos, M. T., Schleif, R., Bairoch, A., Hofmann, K. \& Ramos, J. L. (1997). AraC/XylS family of transcriptional regulators. Microbiol Mol Biol Rev 61, 393-410.

Gong, S., Richard, H. \& Foster, J. W. (2003). YjdE (AdiC) is the arginine:agmatine antiporter essential for arginine-dependent acid resistance in Escherichia coli. J Bacteriol 185, 4402-4409.

Gong, S., Ma, Z. \& Foster, J. W. (2004). The Era-like GTPase TrmE conditionally activates gadE and glutamate-dependent acid resistance in Escherichia coli. Mol Microbiol 54, 948-961.

Gorden, J. \& Small, P. L. C. (1993). Acid resistance in enteric bacteria. Infect Immun 61, 364-367.
Hersh, B. M., Farooq, F. T., Barstad, D. N., Blankenshorn, D. L. \& Slonczewski, J. L. (1996). A glutamate-dependent acid resistance gene in Escherichia coli. J Bacteriol 178, 3978-3981.

Hommais, F., Krin, E., Laurent-Winter, C., Soutourina, O., Malpertuy, A., Le Caer, J. P., Danchin, A. \& Bertin, P. (2001). Large-scale monitoring of pleiotropic regulation of gene expression by the prokaryotic nucleoidassociated protein, H-NS. Mol Microbiol 40, 20-36.

Iyer, R., Williams, C. \& Miller, C. (2003). Arginine-agmatine antiporter in extreme acid resistance in Escherichia coli. J Bacteriol 185, 6556-6561.

Jung, I. L. \& Kim, I. G. (2003). Polyamines and glutamate decarboxylase-based acid resistance in Escherichia coli. J Biol Chem 278, 22846-22852.

Karpel, R., Alon, T., Glaser, G., Schuldiner, S. \& Padan, E. (1991). Expression of a sodium proton antiporter (NhaA) in Escherichia coli is induced by $\mathrm{Na}^{+}$and $\mathrm{Li}^{+}$ions. J Biol Chem 266, 21753.

Kroll, R. G. \& Booth, I. R. (1983). The relationship between intracellular $\mathrm{pH}$, the $\mathrm{pH}$ gradient and potassium transport in Escherichia coli. Biochem J 216, 709-716.

Lewinson, O., Padan, E. \& Bibi, E. (2004). Alkalitolerance: a biological function for a multidrug transporter in $\mathrm{pH}$ homeostasis. Proc Natl Acad Sci U S A 101, 14073-14078.

Lin, J., Lee, I. S., Frey, J., Slonczewski, J. L. \& Foster, J. W. (1995). Comparative analysis of extreme acid survival in Salmonella typhimurium, Shigella flexneri and Escherichia coli. J Bacteriol 177, 4097-4104.

Lo, C. J., Leake, M. C. \& Berry, R. M. (2006). Fluorescence measurement of intracellular sodium concentration in single Escherichia coli cells. Biophys J 90, 357-365.

Ma, Z., Richard, H., Tucker, D. L., Conway, T. \& Foster, J. W. (2002). Collaborative regulation of Escherichia coli glutamate-dependent acid resistance by two AraC-like regulators, GadX and GadW (YhiW). J Bacteriol 184, 7001-7012.

Ma, Z., Richard, H. \& Foster, J. W. (2003a). pH-Dependent modulation of cyclic AMP levels and GadW-dependent repression of RpoS affect synthesis of the GadX regulator and Escherichia coli acid resistance. J Bacteriol 185, 6852-6859.

Ma, Z., Gong, S., Richard, H., Tucker, D. L., Conway, T. \& Foster, J. W. (2003b). GadE (YhiE) activates glutamate decarboxylase-dependent acid resistance in Escherichia coli K-12. Mol Microbiol 49, 1309-1320.

Ma, Z., Masuda, N. \& Foster, J. W. (2004). Characterization of EvgASYdeO-GadE branched regulatory circuit governing glutamate-dependent acid resistance in Escherichia coli. J Bacteriol 186, 7378-7389.

Malashkevich, V. N., De Biase, D., Markovic-Housley, Z., Schlunegger, M. P., Bossa, F. \& Jansonius, J. N. (1998). Crystallization and preliminary X-ray analysis of the beta-isoform of glutamate decarboxylase from Escherichia coli. Acta Crystallogr D Biol Crystallogr 54, 1020-1022.

Masuda, N. \& Church, G. M. (2002). Escherichia coli gene expression responsive to levels of the response regulator EvgA. J Bacteriol 184, 6225-6234.

Masuda, N. \& Church, G. M. (2003). Regulatory network of acid resistance genes in Escherichia coli. Mol Microbiol 48, 699-712.

Miller, J. H. (1992). A Short Course in Bacterial Genetics: a Laboratory Manual and Handbook for Escherichia coli and Related Bacteria. Cold Spring Harbor, NY: Cold Spring Harbor Laboratory.

Nasser, W. \& Reverchon, S. (2007). New insights into the regulatory mechanisms of the LuxR family of quorum sensing regulators. Anal Bioanal Chem 387, 381-390.

Opdyke, J. A., Kang, J. G. \& Storz, G. (2004). GadY, a small-RNA regulator of acid response genes in Escherichia coli. J Bacteriol 186, 6698-6705. 
Padan, E., Zilberstein, D. \& Schuldiner, S. (1981). pH homeostasis in bacteria. Biochim Biophys Acta 650, 151-166.

Padan, E., Bibi, E., Ito, M. \& Krulwich, T. A. (2005). Alkaline pH homeostasis in bacteria: new insights. Biochim Biophys Acta 1717, 67-88.

Price, S. B., Wright, J. C., DeGraves, F. J., Castanie-Cornet, M. P. \& Foster, J. W. (2004). Acid resistance systems required for survival of Escherichia coli O157:H7 in the bovine gastrointestinal tract and in apple cider are different. Appl Environ Microbiol 70, 4792-4799.

Rahav-Manor, O., Carmel, O., Karpel, R., Taglicht, D., Glaser, G., Schuldiner, S. \& Padan, E. (1992). NhaR, a protein homologous to a family of bacterial regulatory proteins (LysR), regulates nhaA, the sodium proton antiporter gene in Escherichia coli. J Biol Chem 267, 10433-10438.

Richard, H. T. \& Foster, J. W. (2003). Acid resistance in Escherichia coli. Adv Appl Microbiol 52, 167-186.

Richard, H. \& Foster, J. W. (2004). Escherichia coli glutamate- and arginine-dependent acid resistance systems increase internal $\mathrm{pH}$ and reverse transmembrane potential. J Bacteriol 186, 6032-6041.

Sayed, A. K., Odom, C. \& Foster, J. W. (2007). The Escherichia coli AraC-family regulators GadX and GadW activate gadE, the central activator of glutamate-dependent acid resistance. Microbiology 153, 2584-2592.

Shijuku, T., Saito, H., Kakegawa, T. \& Kobayashi, H. (2001). Expression of sodium/proton antiporter $\mathrm{NhaA}$ at various $\mathrm{pH}$ values in Escherichia coli. Biochim Biophys Acta 1506, 212-217.

Shin, S., Castanie-Cornet, M. P., Foster, J. W., Crawford, J. A., Brinkley, C. \& Kaper, J. B. (2001). An activator of glutamate decarboxylase genes regulates the expression of enteropathogenic Escherichia coli virulence genes through control of the plasmidencoded regulator, Per. Mol Microbiol 41, 1133-1150.
Small, P. L. C. (1998). Shigella and Escherichia coli strategies for survival at low pH. Jpn J Med Sci Biol 51, S81-S89.

Small, P., Blankenhorn, D., Welty, D., Zinser, E. \& Slonczewski, J. L. (1994). Acid and base resistance in Escherichia coli and Shigella flexneri: role of rpoS and growth pH. J Bacteriol 176, 1729-1737.

Texter, E. C., Jr (1968). Pressure and transit in the small intestine. The concept of propulsion and peripheral resistance in the alimentary canal. Am J Dig Dis 13, 443-454.

Tramonti, A., Visca, P., De Canio, M., Falconi, M. \& De Biase, D. (2002). Functional characterization and regulation of $\mathrm{gadX}$, a gene encoding an AraC/XylS-like transcriptional activator of the Escherichia coli glutamic acid decarboxylase system. J Bacteriol 184, 2603-2613.

Tramonti, A., De Canio, M., Delany, I., Scarlato, V. \& De Biase, D. (2006). Mechanisms of transcription activation exerted by GadX and GadW at the gadA and gadBC gene promoters of the glutamate-based acid resistance system in Escherichia coli. J Bacteriol 188, 8118-8127.

Vogel, H. J. \& Bonner, D. M. (1956). Acetylornithase of Escherichia coli: partial purification and some properties. J Biol Chem 218, 97-106.

Withers, H., Swift, S. \& Williams, P. (2001). Quorum sensing as an integral component of gene regulatory networks in Gram-negative bacteria. Curr Opin Microbiol 4, 186-193.

Zilberstein, D., Agmon, V., Schuldiner, S. \& Padan, E. (1982). The sodium/proton antiporter is part of the $\mathrm{pH}$ homeostasis mechanism in Escherichia coli. J Biol Chem 257, 3687-3691.

Zwir, I., Shin, D., Kato, A., Nishino, K., Latifi, T., Solomon, F., Hare, J. M., Huang, H. \& Groisman, E. A. (2005). Dissecting the PhoP regulatory network of Escherichia coli and Salmonella enterica. Proc Natl Acad Sci U S A 102, 2862-2867.

Edited by: D. J. Jamieson 